\title{
Breaching of an ice dam at Qorlortossup tasia, south Greenland
}

\author{
Christoph MAYER, ${ }^{1,2}$ Thomas V. SCHULER ${ }^{3}$ \\ ${ }^{1}$ Geological Survey of Denmark and Greenland, Øster Voldgade 10, DK-1350 Copenhagen, Denmark \\ ${ }^{2}$ Commission for Glaciology, Bavarian Academy of Sciences, Marstallplatz 8, D-80539 Munich, Germany \\ E-mail: Christoph.Mayer@Irz.badw-muenchen.de \\ ${ }^{3}$ Department of Geosciences, University of Oslo, PO Box 1047 Blindern, NO-0316 Oslo, Norway
}

\begin{abstract}
In July 2003 an ice-dammed lake was suddenly drained in an outburst flood at Qorlortorssup tasia in south Greenland, the site of a projected hydropower station. The lake developed during the first decades of the 20th century as a result of the recession of the ice cap in this area. It used to drain over a shallow rock spillway towards Sermeq kangigdleq, the adjacent outlet glacier to the north. In order to assess the hazard potential and the additional water contribution from the enlarged catchment, the glacial lake and its surroundings were investigated. Based on the analysis of available historical data, field investigations and model results, the history of lake generation and the sudden outbreak were reconstructed. With the lake formation the ice dam lost its connection to the ice cap. The flood was initiated after the ice surface became low enough for the lake water to overflow the glacier towards Qorlortorssup tasia basin, creating a gully through the glacier which drained approximately $55 \times 10^{6} \mathrm{~m}^{3}$ of water over a period of 8-10 days. Thanks to the stability of the dam and the downstream damping of the flood, there was no serious threat to a farm that is situated close to the planned powerstation site. In the future, we expect much smaller floods, as a result of partial closure of the gully by ice movement or snowdrift in the winter. The new drainage pattern into Qorlortorssup tasia basin, however, will be a permanent situation. The amount of this new water contribution can only be roughly estimated since the exact size of the drainage basin is not well known.
\end{abstract}

\section{INTRODUCTION}

Qorlortorsuaq is the site for a hydropower plant which will supply the towns of Qaqortoq and Narsaq in south Greenland with energy. Water is supplied from a nearly glacierfree drainage basin upstream of Amitsuarssuk fjord, a northeastern tributary to Lichtenau fjord. Several lakes exist in this drainage basin. One of them, Qorlortorssup tasia, drains over a large cascade (Qorlortorsuaq, 'the large waterfall') and is the designated water reservoir of the power plant (Fig. 1). At the northeastern border of the drainage area an ice barrier exists (part of 1AE0001 in the glacier inventory of Greenland; Weidick and others, 1995), which dammed a lake (surface area about $2.24 \mathrm{~km}^{2}$ in 1985; surface elevation about 1050 ma.s.l.). This lake (Figs 1 and 2) used to drain over a narrow rock ridge at its northern margin into the adjacent valley of Sermeq kangigdleq (glacier 1AF0802 in Weidick and others, 1995). During a visit in 1992, it was recognized that the surface of the ice dam, preventing the discharge of the lake towards the Qorlortorssup tasia basin, was about $20 \mathrm{~m}$ higher than the lake level (personal communication from O.B. Olesen, 2003). The ice front at the lake receded about $800-1000 \mathrm{~m}$ between 1942 and 1985, considerably enlarging the lake area. At the beginning of July 2003, a strong increase of water flow was observed at Qorlortorsuaq, partially flooding nearby farmland. A first helicopter inspection on 2 July 2003 by Greenland Resources A/S revealed that the glacial dam was penetrated and the lake water flowed into the Qorlortorssup tasia basin. The lake level of Qorlortorssup tasia had risen by $>0.5 \mathrm{~m}$, strongly increasing the outflow over the cascade. In order to evaluate the potential future risk and the consequences of this breach in the ice dam, a glaciological assessment study was carried out.

\section{OBSERVATIONS AT THE LAKE}

Field measurements took place during 9 and 10 July 2003. Compared to photographs from 2 July 2003, the trench in the ice barrier had deepened considerably and the outflow of water seemed to equal the inflow to the lake from the ice cap. There was no detectable change in channel depth or lake level between the two days. The spillway, where the lake drained formerly, was well above the new lake level. The water level at downstream Qorlortorssup tasia was declining at this time but still above its normal level.

\section{Geometry of the lake and drainage channel}

Primarily, the drainage-channel generation and potential dangers associated with the overtopping need to be assessed. To provide a data basis, the new glacier geometry and lake geometry was surveyed. As geographic reference and for use in a future aerial photogrammetric survey, several global positioning system (GPS) locations were marked as control points (Fig. 2). These GPS positions have been interconnected by a terrestrial survey, including the highest point of the ice dam, two positions at the old lake shore and one position each at the new lake shore and in the centre of the former spillway. The depth of the new gully, which now conducts the lake water towards Qorlortorssup tasia, was measured from the helicopter (location S1 in Fig. 2) with a rope down to the water level because ground-based measurements close to the gully edge were too dangerous.

In addition to the measurements at the lake, a series of pictures taken from the shore and from the helicopter were used to extrapolate the point measurements in space. These pictures were also compared with aerial photographs from 1942 and the available electronic map, which is based on 


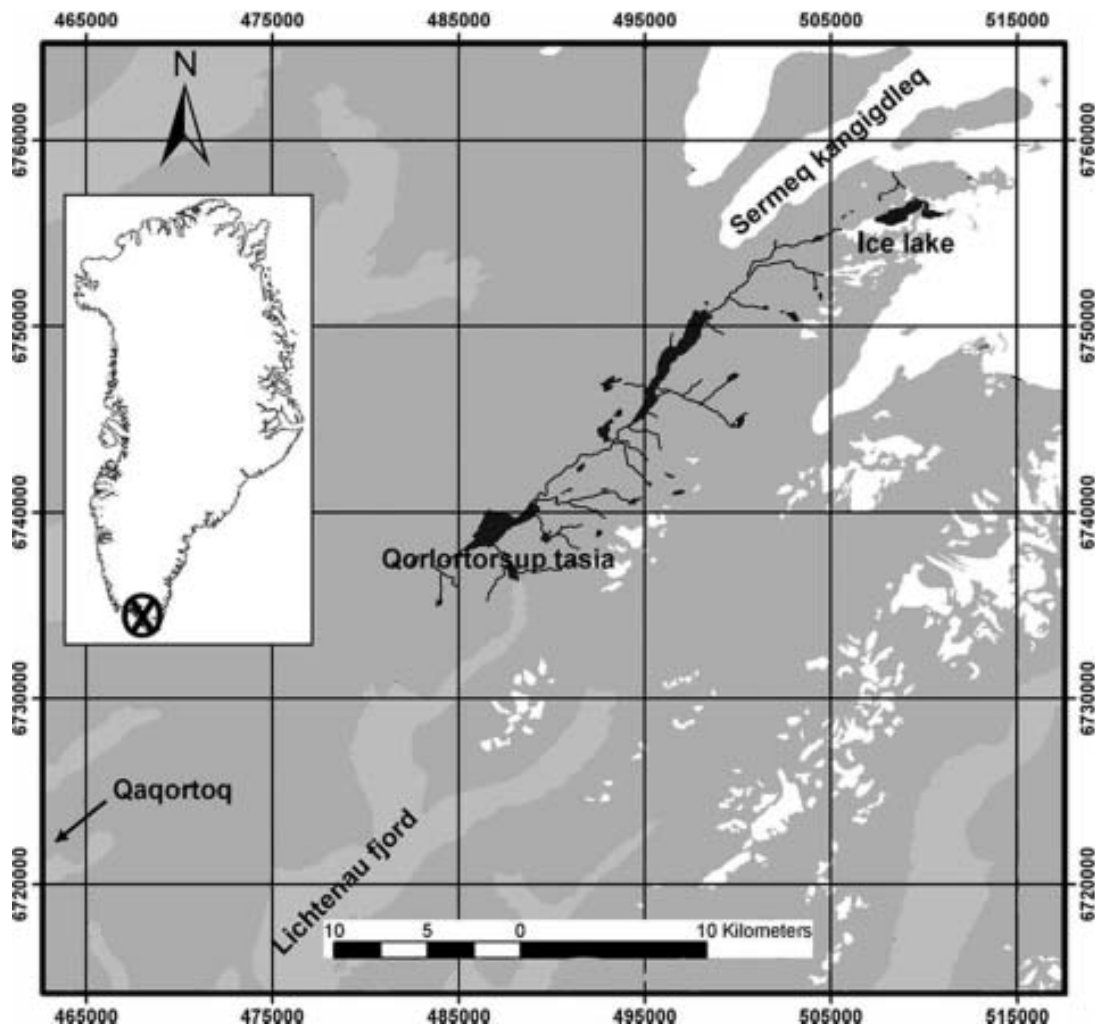

Fig. 1. Overview of the location in Greenland (inset), the area of Qorlortorssup tasia and the ice-dammed lake, with the adjacent ice cap (white) and the fjord system (light grey); lakes are shown in black (map based on Schjøth and others, 2000, map projection UTM/WGS84). For a better overview, only the drainage system of Qorlortorssup tasia is shown.

information from 1985 and a Landsat-5 scene from 1993 (Schjøth and others, 2000).

The accuracy of the GPS measurements lies within $5-10 \mathrm{~m}$ and is comparable with the accuracy of related features in the map $(\mathrm{G} / 250$ vector $\mathbb{C}$ KMS (Danish Cadastral Survey), 1998). The uncertainty of the distance measurements using the total station is less than a few centimetres, whereas the vertical positioning is affected by refraction

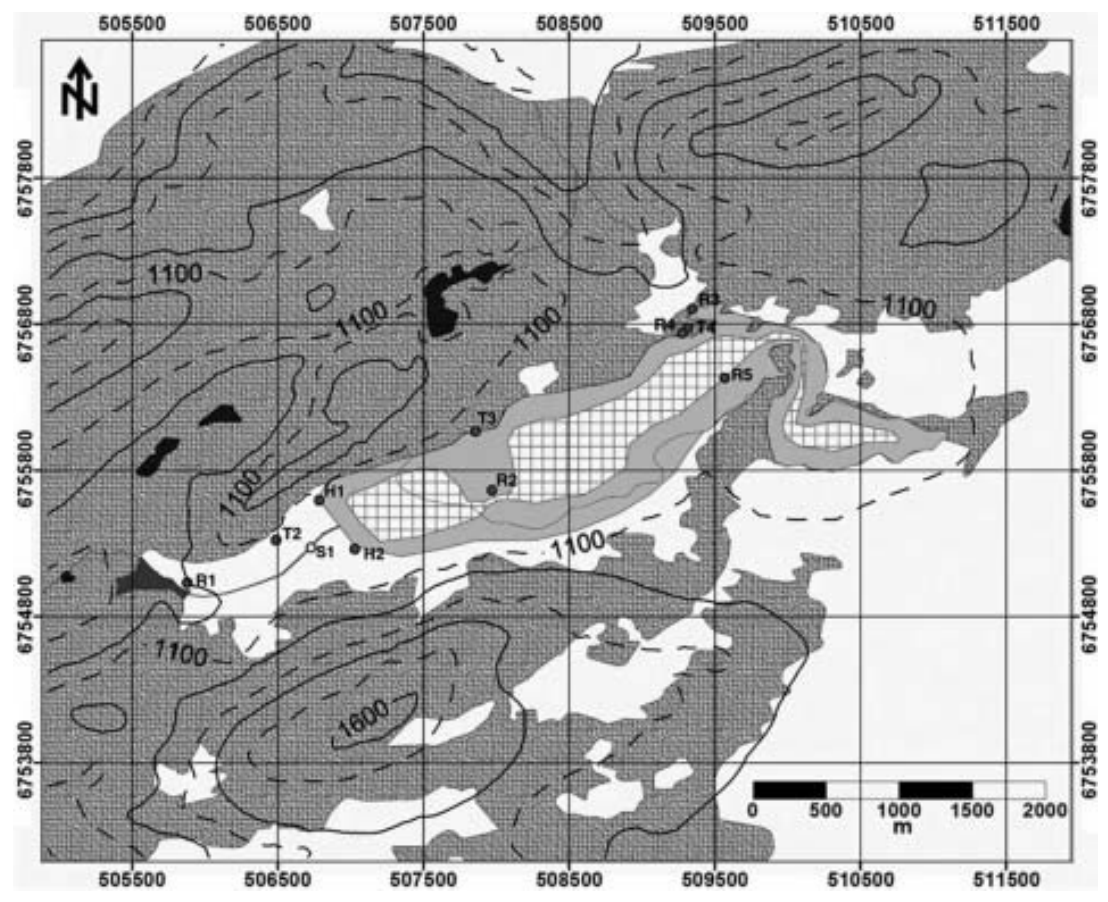

Fig. 2. Lake geometry before (light grey) and after (hatched area) the breaching event, including the positions of the terrestrial survey. The thin line inside the lake area indicates the lake margins in 1985. The former spillway of the lake was situated at position R3. Glacierized areas are shown in white, and other lakes in black. The map projection is UTM/WGS84 and the elevation contour interval is $100 \mathrm{~m}$. 
uncertainties. A comparison of independent height measurements of the old lake shore at two different positions (T3 and $\mathrm{R} 4$ in Fig. 2), relative to a fixed point (R2), showed a difference of only $25 \mathrm{~cm}$ over a distance of $1600 \mathrm{~m}$. Thus, the accuracy of the vertical measurements is estimated to be better than $25-30 \mathrm{~cm}$. The gully depth measurement is affected by the uncertain height of the helicopter above the ice surface. The value of $48.5 \mathrm{~m}$, however, should be accurate within $2 \mathrm{~m}$. The uncertainty of the new lake surface area and of the corresponding lake volume, derived from the survey, is estimated to be $20 \%$.

\section{LAKE DRAINAGE}

At the time of the survey, the outflow from the glacial lake into Qorlortorssup tasia basin was reduced to about the discharge corresponding to the inflow from the upstream glacial basin. The water flowed through a gully in the ice dam which is about $1100 \mathrm{~m}$ long, $10-15 \mathrm{~m}$ wide and at maximum almost $50 \mathrm{~m}$ deep. Surface features of widespread water flow over the entire glacier length clearly indicated that the channel formation started by overtopping the glacial dam (Fig. 3).

According to the analysis of available images and maps, the lake area increased from about $1.7 \mathrm{~km}^{2}$ in 1942 to $2.25 \mathrm{~km}^{2}$ in 1985 . During the same time the front of the dam retreated roughly $1000 \mathrm{~m}$, followed by a further retreat of $600 \mathrm{~m}$ between 1985 and 2003. The final maximum extent of the lake in 2003 was $2.9 \mathrm{~km}^{2}$. The length of the ice barrier, preventing the lake from draining into Qorlortorssup tasia basin, was reduced by $60 \%$ to $1100 \mathrm{~m}$ during this period. Over the last 11 years, the glacier surface melted down approximately $20 \mathrm{~m}$, finally reaching the lake surface level. This corresponds to a net mass balance of $-1.8 \mathrm{~m} \mathrm{a}^{-1}$, which is slightly more negative than the observed net mass-balance values at comparable altitudes on the south Greenland ice sheet $\left(-1.4 \mathrm{~m} \mathrm{a}^{-1}\right.$; Podlech and others, 2004). At present, the highest point of the glacier is only $1.8 \mathrm{~m}$ above the lake level at the onset of the flood, whereas the central part of the glacier is at least $2 \mathrm{~m}$ lower than the northern margin.

The former lake is now divided into two smaller basins (Fig. 2). The level of the larger, main lake is $27 \mathrm{~m}$ below the original lake level. The uppermost part, close to the margin of the ice cap, is divided into several smaller ponds, which are situated several metres higher than the main lake. The level of the smaller lake at the glacier dam is roughly $12 \mathrm{~m}$ below the main lake. This gives a height difference between the lower lake and the deepest part of the glacier gully of about $10 \mathrm{~m}$. At the time of the visit, the water plunged over an ice spillway into the gully. If there is no bedrock or morainic threshold underneath the ice, the lake level of the smaller lake potentially could be reduced by a further $10 \mathrm{~m}$, due to ongoing basal erosion/melting of the ice bed. The deepest part of the gully, however, is only a few metres higher than the final outlet, inhibiting further lowering of the lake level. Also, the water in the ice gully runs already over bedrock for more than half of the gully length, as observed from the helicopter.

The size of total lake surface area at the time of the visit was reduced to $1.18 \mathrm{~km}^{2}$, a reduction by almost $60 \%$ from the maximum extent. The smaller, lower lake accounts for only $0.25 \mathrm{~km}^{2}$. The total amount of water that drained within 8-10 days after the onset of the flood was estimated to be about $55 \times 10^{6} \mathrm{~m}^{3}$. In case of a further reduction of the

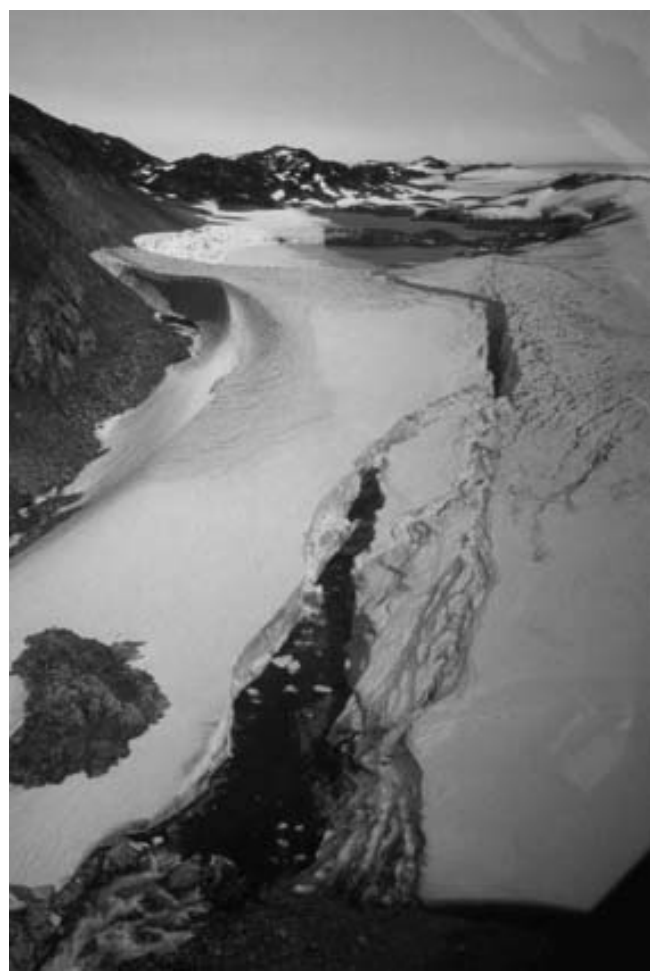

Fig. 3. Photograph of the drainage channel cut through the glacier, with the drained lake in the background. The partition into two lakes at different levels is apparent.

lower lake level by $10 \mathrm{~m}$, another $2 \times 10^{6} \mathrm{~m}^{3}$ may have drained during the days following the visit, before the outflow stabilized. A minor water contribution can still be expected from melting of ice blocks that may break off the gully walls in future.

\section{THE NUMERICAL LAKE-DRAINAGE MODEL}

To reconstruct the temporal evolution of the flood, we used a numerical model, describing the lake drainage through an ice-walled channel which is progressively enlarged by melting as energy is dissipated by the water flow. For this purpose, we adopt the model of Raymond and Nolan (2000) who report a similar lake drainage by overtopping the ice dam at Black Rapids Glacier, Alaska, USA. The model formulation implies a number of simplifying assumptions, which can be justified by the observations at the Qorlortorsuaq ice lake: The channel has constant slope $\alpha$ and the depth of the flowing water $h$ is constant along the channel. We further assume that the channel has a rectangular crosssection, the width of which, $B$, is much larger than the water depth $h$. Enlargement occurs exclusively by down-melting the bottom of the channel. If the temperature of the lake water is above freezing, the temperature drops linearly to freezing at the exit of the channel.

For a channel with width $B$ much larger than the depth of the flowing water $h$, the Manning-Strickler formula to describe discharge can be written

$$
Q=k h^{\frac{5}{3}} \alpha^{\frac{1}{2}} B \text {. }
$$

Here, $k$ denotes the Strickler roughness coefficient. The water depth is given by $h=z_{l}-z_{c_{1}}$ the elevation difference between the lake level $z_{l}$ and the channel floor $z_{C}$ at the lake exit. Drainage occurs if $z_{l}>z_{c}$, otherwise $Q=0$. From 
Table 1. Physical constants

\begin{tabular}{lcc}
\hline Physical property & Value & Unit \\
\hline Gravity acceleration $g$ & 9.8 & $\mathrm{~m} \mathrm{~s}^{-2}$ \\
Density of ice $\rho_{\mathrm{i}}$ & 900 & $\mathrm{~kg} \mathrm{~m}^{-3}$ \\
Density of water $\rho_{\mathrm{w}}$ & 1000 & $\mathrm{~kg} \mathrm{~m}^{-3}$ \\
Latent heat of melting $L_{\mathrm{f}}$ & 333.5 & $\mathrm{~kJ} \mathrm{~kg}^{-1}$ \\
Specific heat of water $C_{\mathrm{w}}$ & $4.22 \times 10^{-3}$ & $\mathrm{~J} \mathrm{~kg} \mathrm{~K}^{-1}$ \\
\hline
\end{tabular}

conservation of energy, we derive an expression for the evolution of $z_{\mathrm{C}}$

$$
\frac{\mathrm{d} z_{\mathrm{C}}}{\mathrm{d} t}=-\frac{\rho_{\mathrm{w}} g}{\rho_{\mathrm{i}} L B} Q\left(\alpha+c_{\mathrm{w}} \frac{\Delta T}{\lg }\right),
$$

where $\rho_{\mathrm{w} / \mathrm{i}}$ denote the densities of water and ice, respectively, $g$ is acceleration due to gravity and $L$ the latent heat of melting. Used values are given in Table 1. The temperature of the lake water above freezing, $\Delta T$, drops linearly to zero along the length $I$, and $c_{\mathrm{w}}$ is the specific heat of water. The evolution of $z_{1}$ is derived from the water balance of the lake,

$$
\frac{\mathrm{d} z_{\mathrm{l}}}{\mathrm{d} t}=\frac{Q_{\mathrm{i}}-Q}{S\left(z_{\mathrm{l}}\right)}
$$

where $Q_{\mathrm{i}}$ is input discharge to the lake and $S\left(z_{\mathrm{l}}\right)$ is the lake surface area at water level $z_{1}$.

Substituting $Q$ in Equations (2) and (3) with Equation (1) yields a system of two ordinary differential equations which can be solved for the two unknowns $z_{\mathrm{C}}$ and $z_{l}$. The initial value problem was solved using an explicit RungaKutta method.

\section{INITIAL CONDITIONS AND PARAMETER VALUES}

The computation was started from the following initial condition: the lake level was equal to the elevation of the ice dam, $z_{l}=z_{C}=40 \mathrm{~m}$ relative to the outlet of the channel. The channel was $1100 \mathrm{~m}$ long and its slope was 0.012 . From photographs of the channel after termination of the flood (Fig. 3), we determined $B=10 \mathrm{~m}$. We selected $k=30 \mathrm{~m}^{1 / 3} \mathrm{~s}^{-1}$ as a typical value for a mountain stream (e.g. Maidment, 1993). The hypsography of the lake was determined from a digital elevation model that was constructed from air photographs and the ground-based survey after the lake was emptied. Discharge input to the lake was roughly estimated $Q_{\mathrm{i}}=1 \mathrm{~m}^{3} \mathrm{~s}^{-1}$.

\section{SENSITIVITY}

The temperature of the lake water, $T$, during the flood event is not known and we investigate the sensitivity of our model to changes in T. Raymond and Nolan (2000) argued that unstable drainage occurs if the bottom of the channel through the ice dam drops faster than the water level in the lake. They analyzed this condition and derived an expression for the critical lake area which must be exceeded to enable unstable drainage. In the Qorlortorsuaq case, the lake surface area is well constrained by observations while estimates of the lake temperature are uncertain. Here, we analyze the stability of lake drainage as a function of lake temperature. If we neglect $Q_{i}$ and insert Equations (1-3) into $\mathrm{d} z_{\mathrm{C}} / \mathrm{d} t>\mathrm{d} z_{\mathrm{l}} / \mathrm{d} t$, the condition for unstable drainage, we
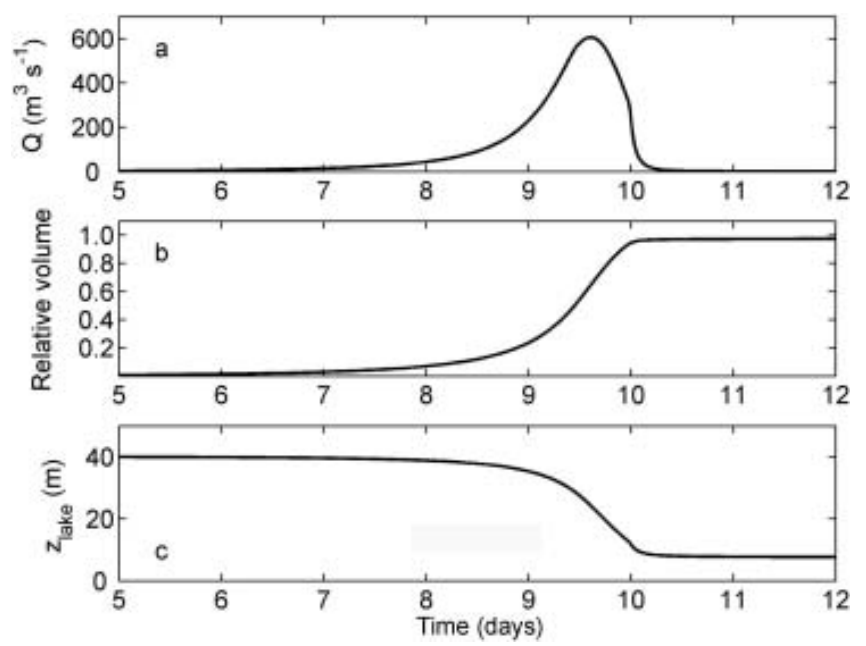

Fig. 4. Model results obtained from the most likely parameter configuration: (a) flood hydrograph; (b) the drained water volume $V$ relative to the original lake volume; and (c) elevation of the lake water level $z_{\text {lake. }}$

obtain an expression for the critical lake temperature

$$
T_{\text {crit }}=\frac{l}{C_{\mathrm{w}}}\left(\frac{\rho_{\mathrm{i}} L B}{\rho_{\mathrm{w}} S}-g \alpha\right) .
$$

For the given situation, the critical lake temperature for unstable drainage is estimated to be $0.25^{\circ} \mathrm{C}$.

From the available observations, it is known that the evolution of the full channel depth lasted 5-10 days. This was deduced from the still rising level of Qorlortossup lake after 5 days and the fully developed channel found during the visit 8 days after the onset of the flood. Considering the duration of the flood, we modelled a number of scenarios to constrain the temperature of the lake water and determine the most likely scenario for the breaching event. As a result, the model predicts that the lake temperature was around $0.45^{\circ} \mathrm{C}$. Model results obtained from using this value suggest that the flood reached a peak discharge of roughly $600 \mathrm{~m}^{3} \mathrm{~s}^{-1}$ (Fig. 4a). Furthermore, the bulk of the water discharged within 6 days, and $97 \%$ of the lake volume was drained roughly 10 days after the onset (Fig. 4b). At that time, the water level was about $8 \mathrm{~m}$ above the lake floor (Fig. 4c), and the still declining discharge was about $6 \mathrm{~m}^{3} \mathrm{~s}^{-1}$.

\section{RECONSTRUCTION OF THE 2003 FLOOD}

Observed trimlines in the area (e.g. Fig. 3, left mountain slope) show that during the last maximum ice extent, probably towards the end of the 19th century, the entire lake basin was filled with a glacier, which was then up to $100 \mathrm{~m}$ above the modern glacier surface. This glacier reached into the Qorlortorssup tasia basin, as well as into the adjacent Sermeq kangigdleq valley. During the general retreat of ice masses in south Greenland since the beginning of the 20th century (Weidick, 1959), ice flow through the Qorlortorsuaq tributary ceased and the ice surface in the recent lake area lowered. The ice flow over the rock spillway into Sermeq kangigdleq was further reduced and the lake started to form, most likely during the 1920s. In 1942, the lake had reached about $60 \%$ of its final maximum size. After the ice dam lost connection with the main ice cap, it started to shrink since 
the equilibrium-line altitude in this area is about $150 \mathrm{~m}$ above the modern ice surface (Podlech and others, 2004).

Most likely, the water started to overtop the ice dam towards Qorlortorssup tasia during the last days of June 2003. This happened first on an approximately $100 \mathrm{~m}$ stretch of the glacier (Fig. 3). The water flow subsequently concentrated in a few erosion channels, which started to merge into one channel at the downstream end of the ice dam. This concentration of water flow eventually reached the lake shore, and further erosion/melting of the channel accelerated the process of channel enlargement. The reason why the ice dam did not become afloat is not entirely clear. Most probably the ice dam is frozen to the ground. Annual mean temperatures are only available for Qaqortoq $\left(0.6^{\circ} \mathrm{C}\right.$ (Hanna and Cappelen, 2003)), which indicates an annual mean temperature of approximately $-5^{\circ} \mathrm{C}$ at the lake. Because the ice dam is not dynamically active, such a mean surface temperature would be low enough for freezing conditions at the ice base.

Due to the length across the ice dam (approximately $1100 \mathrm{~m})$, a catastrophic outburst by a mechanical failure of the ice dam or an isostatic uplift of the ice mass did not occur. Instead, the downward erosion of the drainage gully caused a progressively increasing discharge from the lake. Further downstream, the flood was reduced by the retention of the Qorlortorssup tasia basin, which measures $23 \mathrm{~km}$ in length from the glacier.

For glacier outburst floods, Clague and Mathews (1973) established the relation $Q_{p}=a V^{b}$ to estimate the peak discharge $Q_{p}$ based on the lake volume $V$ (in $10^{6} \mathrm{~m}^{3} \mathrm{~s}^{-1}$ ) ( $\mathrm{Ng}$ and Björnsson, 2003). Walder and Costa (1996) determined the parameter values $a=46$ and $b=2 / 3$ for outburst floods through a subglacial channel and $a=1100$ and $b=0.44$ for floods through a subaerial breach. Using both parameter sets and $V=55$ for Qorlortossup tasia, we obtain $675 \mathrm{~m}^{3} \mathrm{~s}^{-1}$ and $6415 \mathrm{~m}^{3} \mathrm{~s}^{-1}$, respectively. The first value is in close agreement with the $\sim 600 \mathrm{~m}^{3} \mathrm{~s}^{-1}$ of our reconstruction (Fig. 4a), while the second value overestimates $Q_{p}$ by one order of magnitude. We explain this behavior with the qualitative similarity of drainage through a subglacial channel and through the subaerial channel at Qorlortossup tasia. In both cases, the evolution of an outburst flood is controlled by melting of the channel walls due to viscous dissipation of the water flow, while Walder and Costa (1996) considered subaerial outbursts which were controlled by a mechanical failure of the ice dam. This is also supported by the negative skewness of the hydrograph in Figure 4a, indicative for a flood pathway that is progressively enlarged during the flood.

We believe that the channel is kept open as long as there is some water flow through it. During winter, the water discharge will cease due to the low temperatures prohibiting meltwater production, and the channel may close by ice creep. We estimated the closure rate based on a simple evaluation of the geometry of the gully and prevailing ice conditions (close to the melting point). With a simple but appropriate assumption of simple shear (Paterson, 1994, p. 259ff.), the horizontal velocity $u_{x}$ changes with depth $z$ according to

$$
\frac{\partial u_{x}}{\partial z}=A \tau_{x z^{\prime}}^{3}
$$

where $A$ is the rate factor in Glen's flow law for ice and $\tau_{x z}$ is the shear stress. In this case, $\tau_{x z}$ is given by the hydrostatic pressure of the overburden ice. Evaluating Equation (5) over an ice depth of $40 \mathrm{~m}$ and using $A=3.0 \times 10^{-15} \mathrm{kPa}^{-3}$, we find that during one winter period the strain rate is large enough only to close the lowermost $15 \mathrm{~m}$ of the $10 \mathrm{~m}$ wide gully. The winter of 2003/04 has shown that snowdrift into the gully led only to a partial filling of the gully which was not enough to retain considerable amounts of water (personal communication from R. Andersen, 2004). Therefore, we exclude the occurrence of a flood comparable in size to the observed event for the near future, as long as the prevailing climatic conditions exist.

Before the 2003 outburst, the local glacier contributed only small quantities of meltwater to the catchment of Qorlortorssup tasia (in the order of $10^{5} \mathrm{~m}^{3} \mathrm{a}^{-1}$ ). Now, the entire drainage basin of the glacier lake contributes to Qorlortorssup tasia. Previous estimates yielded a potential annual contribution of roughly $14 \times 10^{6} \mathrm{~m}^{3}$ (personal communication from O.B. Olesen, 2003). However, the area on the ice cap, which drains towards the ice lake, is poorly constrained, and the actual water contribution into the Qorlortorssup tasia basin might be considerably larger.

\section{CONCLUSIONS}

The observed flood from the Qorlortorsuaq ice-dammed lake during July 2003 was a consequence of continuous glacier recession. After the separation of the ice dam from the feeding ice cap, it cannot be maintained under present climate conditions. The water impounded in the lake overtopped the ice dam and created a gully through which almost the entire lake emptied within 10 days. Fortunately, human settlements were far enough from the lake not to be threatened by this event. A complete closure of the eroded gully is very unlikely and the new drainage pattern will persist. Therefore, the potential flood hazard in the Qorlortorssup tasia area is small. The increase in water supply for the planned hydropower plant might be up to 30$50 \%$ of the discharge over the waterfall of Qorlortorsuaq before the flood. The effect of additional glacial meltwater contribution during the summer months should be taken into account in the design of the hydropower plant.

\section{ACKNOWLEDGEMENTS}

T.V. Schuler gratefully acknowledges a grant of the Deutsche Forschungsgemeinschaft. C. Mayer thanks Greenland Resources A/S for enabling fieldwork at the glacier lake. We further appreciate the comments of M. Funk, H. Björnsson and N. Reeh (Scientific Editor) which helped to improve an earlier version of the paper.

\section{REFERENCES}

Clague, J.J. and W.H. Mathews. 1973. The magnitude of jökulhlaups. J. Glaciol., 12(66), 501-504.

Hanna, E. and J. Cappelen. 2003. Recent cooling in coastal southern Greenland and relation with the North Atlantic Oscillation. Geophys. Res. Lett., 30(3), 1132. (10.1029/ 2002GLO15797.)

Maidment, D.R. 1993. Handbook of hydrology. New York, McGraw-Hill.

$\mathrm{Ng}$, F. and H. Björnsson. 2003. On the Clague-Mathews relation for jökulhlaups. J. Glaciol., 49(165), 161-172.

Paterson, W.S.B. 1994. The physics of glaciers. Third edition. Oxford, etc., Elsevier. 
Podlech, S., C. Mayer and C.E. Bøggild. 2004. Glacier retreat, mass balance and thinning: the Qagssimiut ice margin, South Greenland. Geogr. Ann., 86A(4), 305-317.

Raymond, C.F. and M. Nolan. 2000. Drainage of a glacial lake through an ice spillway. In Debris-Covered Glaciers. Wallingford, Oxon., International Association of Hydrological Sciences, 199-207. (IAHS publication 264.)

Schjøth, F. and 11 others. 2000. Mineral resource potential of South Greenland: the CD-ROM. Danmarks og Grønlands Geologiske Undersøgelse Rapport 2000/57.
Walder, J.S. and J.E. Costa. 1996. Outburst floods from glacier-dammed lakes: the effect of mode of lake drainage on flood magnitude. Earth Surf. Proc. Land., 21(8), 701-723.

Weidick, A. 1959. Glacial variations in West Greenland in historical time. Part I. South West Greenland. Bull. Grønl. Geol. Unders. 18.

Weidick, A., C.E. Bøggild and N.T. Knudsen. 1995. Glacier inventory and atlas of West Greenland. Rapp. Grønl. Geol. Unders. 158. 